\title{
Variable success of biological control \\ of Lythrum salicaria in British Columbia
}

\section{MADLEN DENOTH ${ }^{1}$ \\ JUDITH H. MYERS}

Department of Zoology, The University of British Columbia

Corresponding Author:

Madlen Denoth

UBC Department of Zoology, 6270 University Boulevard

Vancouver, B.C.

V6T 1Z4

Phone: (604) 822-3957

Fax: (604) 822-2416

E-mails: denoth@zoology.ubc.ca, myers@zoology.ubc.ca

${ }^{1}$ Present address:

Département de biologie

Unité d'écologie \& évolution

Université de Fribourg

Chemin du Musée 10

1700 Fribourg

Switzerland

Published in "Biological Control 32 (2005) 269-279"

which should be cited to reference this work.

doi:10.1016/j.biocontrol.2004.10.006 


\begin{abstract}
Purple loosestrife, Lythrum salicaria, has invaded North American wetlands over the last 200 years. A biological control project was started in British Columbia, Canada, in 1993 with the introduction of Galerucella calmariensis, a leaf-feeding beetle of European origin. To evaluate the success of the biological control project in the Lower Mainland of British Columbia, we monitored the defoliation levels of Lythrum at 10 release sites of the control agent, identified factors associated with among-site variability in defoliation levels, and determined the effect of defoliation on the performance and abundance of Lythrum. In tidal areas, the beetles could not establish due to tidal disturbances. The control agent established at all nontidal sites, but defoliation levels varied considerably. Defoliation levels were negatively associated with predation on Galerucella eggs, suggesting that general predators may be able to prevent or delay successful biological control of Lythrum. Eggs on Lythrum stems surrounded by water experienced lower predation rates than eggs on stems on land, indicating that standing water acts as a partial refuge against predators for Galerucella eggs. Flower-bud density, length of inflorescence, and plant biomass per $\mathrm{m}^{2}$ were all negatively related with the intensity of beetle feeding, and stem height was marginally reduced with increased beetle grazing. Dry biomass per $\mathrm{m}^{2}$ of Lythrum appeared to decline drastically only at sites where beetle grazing was intense.
\end{abstract}

Keywords: Purple loosestrife; Lythrum salicaria; Galerucella calmariensis; Control agent establishment; Insect outbreak; Predation; Plant quality; Tidal disturbance; Cumulative feeding effects

\title{
1. Introduction
}

It is not uncommon for the success of a biological control project to vary with geographic region and habitat, associated with differences in the biotic and abiotic environments. When biocontrol projects are not successful, it is generally due to the failure of a biological control agent to establish or to exert enough predation pressure on the weed to lower its abundance or biomass (Sheppard, 1992). Among other factors, habitat stability is well known to influence control-agent establishment, with stable habitats such as forests showing higher rates of establishment of control agents than disturbed habitats such as agricultural fields (Cameron et al., 1993; Hall and Ehler, 1979). Once established, a prerequisite for the control agent's ability to suppress the weed at a given release site is a sufficiently high density of the agent. Local parasitoids and predators are frequently blamed for preventing the populations of the control agents from reaching high densities (Goeden and Louda, 1976). Alternatively, host-plant quality can play a decisive role in determining the abundance of the control agent: an agent can be successful in one environment, but not in another due to the poor quality of the host plant at one site that does not allow population growth of the control agent (e.g., Room, 1990).

Even when high population densities are reached, however, some control agents do not control their hosts (Cullen and Snowball, 1979) because they do not cause debilitating damage to the host plant or kill it. Among the most successful control agents are leaf-chewing insects (Crawley, 1989) because repeated, severe defoliations deplete a plant's reserves. The attacked 
plants eventually die and a decline in plant density can result. In many plant species, a threshold level of defoliation exists below which individual performance is not significantly affected due to compensation following herbivory (Hendrix, 1988), a response facilitated by the existence of stored food reserves and axillary buds that allow regrowth. In such plant species, weak herbivory, even when consistent, is unlikely to affect plant survival and density.

The biological control of purple loosestrife, Lythrum salicaria L. (Lythraceae), in North American wetlands by European leaf-feeding chrysomelid beetles is a recent example of repeated biological control success (reviewed in Blossey et al., 2001). Yet, the beetles have not successfully established at all North American sites, nor do they control the abundance of their host plants in all locations. In the Lower Mainland of British Columbia, Lythrum has infested wetlands including sites along the Fraser River that are strongly influenced by tides. Here only one control agent, Galerucella calmariensis L. (Coleoptera: Chrysomelidae), has been widely introduced during the past 11 years. Casual observations have indicated a high variation in beetle densities among release sites. Recent studies have documented that even moderate levels of feeding by Galerucella spp. impact the reproductive and vegetative performance of Lythrum (e.g., Katovich et al., 1999, 2001) in the same year. Lythrum stem density, however, may only be affected after several years of herbivory and when a threshold beetle density has been reached (Lindgren, 2003) due to inaccessible nutrient reserves that allow the plant to compensate for the feeding damage.

Our aims in this study were: (1) to document the spatial and temporal variability in Galerucella calmariensis' feeding damage among the release sites; (2) to identify environmental factor(s) that can explain the variability, and (3) to determine the effects of beetle feeding on Lythrum. As recommended by McEvoy et al. (1991), we used a combination of long-term monitoring and short-term experiments to investigate the success of this biological control project.

\section{Materials and methods}

\subsection{Study system}

Lythrum salicaria is a perennial plant of Eurasian origin that was introduced to North America in the early 1800s and was first recorded in British Columbia as a herbarium specimen, collected in 1897. However, it did not persist and was not reestablished until the 1920s (F. Ganders, University of British Columbia, Vancouver, personal communication). The biology, ecology, history of invasion into North America and the environmental impacts of Lythrum have been described extensively (Anderson, 1991; Blossey et al., 2001; Gaudet and Keddy, 1988; Keddy et al., 2000; Mal et al., 1992; Shamsi and Whitehead, 1974; Thompson et al., 1987). Lythrum grows in a wide range of environmental conditions (Mal et al., 1992 and references therein). The species grows rapidly and up to $2.7 \mathrm{~m}$ in height (Mal et al., 1992) with a high biomass, conferring a strong competitive ability (Gaudet and Keddy, 1988). With increasing age, the number of annual stems produced by individual plants increases to a maximum of 30 to 50 (Mal et al., 1992). Individual plants are long-lived (> 20 years) and have a high survival once they are more than 2 years old (Anderson, 1991). Lythrum seed production is high (estimates range from 100,000 to 2,700 000 per plant per year) and the seeds form an abundant seed bank; the small and light seeds are easily dispersed by water, wind, and animals (Mal et al., 1992 and references therein). Lythrum successfully colonizes open soils and responds positively to many kinds of human and natural disturbances (Rachich and Reader, 1999). Given the tendency of 
Lythrum to occupy sensitive, wet habitats such as stream banks, lakes, and ditches, Hight and Drea (1991) argued that biological control is the most suitable and environmentally safe technique for managing this exotic plant.

To date, mainly one species of insect, Galerucella calmariensis, has been introduced in the Lower Mainland of British Columbia, beginning in 1993 (Table 1). There is an extensive literature on the biology, ecology, and taxonomy of this species (Blossey, 1991, 1995; Blossey and Schat, 1997; Hight and Drea, 1991; Malecki et al., 1993; Manguin et al., 1993; McAvoy et al., 1997; Medina, 1995; Nechols et al., 1996; Sebolt and Landis, 2002; Velarde et al., 2002). The following is a brief summary of the species' life history as it relates to this study.

The adult beetles emerge from the soil in late April to mid-May and feed on leaf tissue of the host plant. Following a period of 7 to 10 days of feeding and mating, the main oviposition period occurs during May and June with reduced egg production until the end of July. Each female can lay up to 500 eggs in small batches of 2 to 10 eggs on the stems, leaves, and leaf axils of Lythrum. Small neonate larvae appear first in early June and crawl to the top leaves to feed. The larvae molt three times with more than $80 \%$ of the larval growth and feeding damage occurring in the last larval instar (Loos and Ragsdale, 1998). Developing larvae move to the underside of leaves and feed extensively on leaf and stem tissue. After two to three weeks of feeding, the larvae move into the soil underneath the host plant to pupate. The adults of the next generation emerge in July, two to three weeks after the larvae have entered the soil. Adult beetles hibernate in the soil or in hollow plant stems when flooding occurs (Schooler, 1998). A low density of new egg masses found in August 1999 at two of the monitoring sites suggests that this species is partially bivoltine in southwest British Columbia.

\subsection{Study sites}

Monitoring and experiments were conducted at 10 sites in the Lower Mainland of British Columbia (Fig. 1), at which the Galerucella spp. beetles had been released by Roy Cranston, the B.C. Ministry of Agriculture, Food and Fisheries, in collaboration with Dr. Judith Myers from the University of British Columbia from 1993 to 1999. The sites are described in more detail in Denoth (2004). Table 1 summarizes the information about the sites and the control agent's releases.

\subsection{Monitoring of Lythrum and Galerucella}

To determine the performance of Lythrum, all sites except MacDonald slough and Iona North marsh were monitored at least once a year, in July or August, from 1999 to 2002. Here, we only report part of this data set, as it pertains to this study.

Following a slightly modified procedure described in Blossey and Skinner (2000), we estimated Lythrum performance at each site by averaging the results recorded in each of 10 to 15 $1-\mathrm{m}^{2}$ quadrats. At three sites with little variability the number of quadrats sampled was as low as five in 2002. Quadrats were $5 \mathrm{~m}$ apart on straight line transects that were laid in the same general area each time a site was visited. Transect starting points were selected subjectively to facilitate the accessibility to sampling quadrats. Lythrum abundance was estimated by counting the number of stems in each quadrat. To estimate biomass, 30 shoots consisting of the three tallest and the three shortest Lythrum stems in the first five sampling quadrats, were cut at their base and dried at $80^{\circ} \mathrm{C}$ for $48 \mathrm{~h}$. Average Lythrum plant biomass per $\mathrm{m}^{2}$ for the $j$ th site, $A_{j}$, was computed as: 


$$
A_{j}=\frac{d_{j}}{30} \sum_{i=1}^{n} \frac{a_{i j}}{n_{j}}
$$

where $d_{j}=$ combined dry biomass of the three tallest and the three shortest stems sampled in each of five quadrats at the $j$ th site, $a_{i j}=$ number of Lythrum stems in the ith quadrat, and $n_{j}=$ number of quadrats sampled at the $j$ th site.

Lythrum reproductive performance was determined by taking the following measures of the five tallest stems in each quadrats: the length of the inflorescences, the density of flower buds on the inflorescences (number per $5 \mathrm{~cm}$ ), and the number of inflorescences per stem. Lythrum vegetative performance was estimated by recording the number of stems per quadrat and by measuring the height of the five tallest stems. Only quadrats with a minimum of five stems were selected to allow an equal number of measurements in each quadrat.

Galerucella feeding damage was determined at each site by subjectively estimating the amount of Lythrum foliage removed. One of six damage categories based on the estimated percentage removal of foliage, A: 0\%, B: $\leq 5 \%$, C: 6 - 25\%, D: $26-50 \%$, E: $51-75 \%$, F: $76-$ $100 \%$, was subjectively assigned to the Lythrum stems in each quadrat. The overall feeding damage at a site was computed by averaging the midpoints of all damage categories over all sample quadrats. Therefore, the theoretical maximum feeding damage was $88 \%$.

Galerucella densities were estimated by counting the number of eggs, larvae and adult beetles separately during one minute each in each quadrat. Density estimates of all quadrats per site were averaged.

\subsection{Beetle survival in tidal areas}

To test the hypothesis that disturbance associated with the water movement causes failure of beetle establishment in tidal areas, we carried out a field experiment to determine the effect of tidal flooding on the beetle larvae.

We inoculated twelve individual Lythrum stems with five beetle larvae each in late afternoon of June 14, 2001, at MacDonald slough and determined the number of remaining larvae the next morning, after a high tide. Two treatments were applied: second and third instar larvae were either set on the tips of tall plants, which were not submerged during the high tide, or on small plants that would be submerged. Maximum tide level relative to the Lythrum stems was recorded during the high tide to ensure discriminating treatments to the larvae on tall and small stems, respectively. The data were analyzed using a Mann-Whitney U test.

\subsection{Variation in predation and food-plant quality among sites}

To contrast predation on the beetles and plant quality among sites with high and low defoliation levels, we conducted experiments at four nontidal release areas in 2001. Two of these, Iona North marsh and Jericho Beach Park, had experienced substantial to complete defoliation of Lythrum in 2000, whereas the sites Iona South marsh and Westham showed average defoliation levels of less than 10\% in 1999 and 2000. The densities of Galerucella adult, egg, and larval stages were estimated in $0.25-\mathrm{m}^{2}$ quadrats according to the monitoring procedure described above. Lythrum defoliation levels, predation on the beetles, and plant quality, measured as the weight and mortality, respectively, of larvae protected from predators, were determined at each site. 


\subsubsection{Egg predation}

Egg predation was assessed in mid-May. First, we determined the height distribution of the egg masses at each site from 10 arbitrarily selected Lythrum stems. We then selected one experimental egg mass on each of 50 arbitrarily chosen Lythrum stems such that the height distribution of the experimental egg masses reflected the natural distribution. The position of each egg mass (in 5-cm intervals from the ground) and the number of eggs in the egg masses were recorded. Each egg mass was marked by placing a small dot of Liquid Paper ${ }^{\circledR}$ correction fluid just above it (Nechols et al., 1996). After a 7-day period, we recorded the condition of the eggs. Shrunken eggs, missing eggs, and eggs that had been opened were considered to be preyed upon. The average level of predation for each site was computed for the 50 egg masses.

\subsubsection{Predation on larvae}

To estimate predation on larvae, larvae were exposed to predators at each of the four experimental sites. To assure equal plant quality, the Lythrum plants to receive the experimental larvae were grown in the greenhouse from stem cuttings. Four weeks before the experiment started, Lythrum shoots were harvested at Iona South marsh and immediately transferred to the UBC greenhouse. Here, all except three leaves at the shoot tips were removed, and the shoots were planted singly in plant pots filled with mineral soil and put in a mist bed to develop roots. Water sprinklers and heating cables for bottom heat maintain a humid (80\% relative humidity) and warm $\left(25^{\circ} \mathrm{C}\right)$ climate that encourages plant growth in the mist bed.

We used a total of 20 plants per site. The plants were paired to produce 10 sets: one of the plants was selected randomly and received 10 second-instar larvae; the other plant served as a control for immigrating larvae because larvae disperse from plants when severe defoliation leads to food shortage (personal observations). The control plant was placed at a distance of $20 \mathrm{~cm}$ from the experimental plant. Each pair of plants was considered to be a replicate and was at least $1 \mathrm{~m}$ from other replicates. The potted plants were placed in the soil such that the containers were completely buried. Water for the plants was provided when necessary, usually daily. After a 6day period, the plants were recovered, and the larvae were counted. Missing larvae were considered to have been killed by predators. We assumed that the larval immigration rate did not vary between control and experimental plants. The number of surviving larvae was determined by computing the difference in the number of larvae between each pair of plants to correct for larval immigration. To compute the mean number of surviving larvae at each site, we averaged the number of surviving larvae of all plant pairs.

\subsubsection{Predation on pupae}

To measure predation on pupae, we buried 20 sets of four pupae 1 to $1.5 \mathrm{~cm}$ under the soil surface, in their natural pupation environment, at each of the four experimental sites. To facilitate recovery of the pupae, we placed them on a $10 \mathrm{~cm} \times 10 \mathrm{~cm}$ piece of mesh screen and marked their location with a small wooden stick. The number of recovered pupae was recorded after a week. Missing pupae were considered to have been preyed upon.

\subsubsection{Plant quality}

Plant quality was assessed indirectly by measuring the weight and survival of caged larvae after feeding on individual plants. We caged 10 arbitrarily selected plants in early May to prevent oviposition by adult beetles. When larvae were available, we inoculated each plant with 10 first instar larvae from nearby plants. Since most of the larval growth takes place in the third 
instar (Loos and Ragsdale, 1998), differences in initial larval weight were considered insignificant and were not recorded. Crawling predators were prevented from accessing the plants by applying Stickem ${ }^{\circledR}$ (Phero Tech Inc., Richmond, B.C.) to the base of the cages and the base of the plant stems. After 13 days, the larvae were recovered, counted, and weighed on a Mettler laboratory scale.

\subsubsection{Data analysis}

Each of the four variables examined was correlated individually with the percentage plant damage at each site using Pearson linear correlation. All variables were transformed to meet the assumptions of linear correlation analysis. Angular transformation was used to transform proportions (percentage plant damage, predation rate of eggs), square root transformation was applied to the count variables (surviving larvae, surviving pupae), and larval weights were log transformed. The data could not be analyzed with the use of analysis of variance techniques, since the response variable (defoliation level, measured after the experiments were conducted) was continuous in 2001, with defoliation levels ranging from low (Iona South) to intermediate (Iona North, Jericho) to high (Westham).

\subsection{Influence of water level on egg predation}

To determine if standing water had a protective influence on the eggs of Galerucella, we carried out a predation experiment at Iona South marsh. The site was chosen because individual plants in the water had shown high defoliation levels in 2001, but not plants on land. In 2002, we measured the predation rates of egg masses on Lythrum stems surrounded by water or not surrounded by water. A total of 15 individual Lythrum plants were selected in mid-May, seven in standing water, eight on land. Five egg masses were chosen at regular intervals on each stem and marked with a small dot of Liquid Paper ${ }^{\circledR}$ just above the egg mass. The number of eggs of each egg mass was recorded. After 1 week, we recorded if predation (yes or no) had occurred to each of the egg masses. The mean predation levels per plant stem were compared using a MannWhitney U test.

\subsection{Effects of Galerucella feeding on Lythrum}

We examined the effect of beetle feeding on the reproductive and vegetative performance of Lythrum at six nontidal sites in 2000 by relating the observed feeding damage to Lythrum performance indicators using Spearman rank correlation. To examine the cumulative effect of four years of Galerucella feeding (1999 to 2002) on Lythrum density, we examined the relationship between Lythrum feeding damage and the percent change in stem densities from 1999 to 2002 at the six sites using Spearman rank correlation. We used Lythrum flower-bud density as a surrogate, after establishing that it was a reliable measure of feeding (see results). Changes in Lythrum dry biomass over the monitoring period were only evaluated qualitatively, since dry biomass was estimated from only one sample per site.

\section{Results}

\subsection{Variation in beetle's feeding damage}


Feeding damage to Lythrum varied in space and time (Fig. 2). The beetles failed to establish at any of three tidal sites. At the MacDonald site only, individual adult beetles and negligible feeding damage (below 5\% of foliage removed in all years), but no eggs, larvae or pupae, could be observed at the edges up to three years after the release. The number of sites where beetles occurred at sufficient density to cause complete plant defoliation (henceforth referred to as beetle outbreaks) increased to three by 2002.

A rapid increase in feeding damage, from low feeding damage to complete defoliation, can occur within a year, as shown at the Westham and Colony Farm sites. Once outbreak densities were reached, high Lythrum defoliation levels were usually sustained in the following years. Consistently low herbivory levels were found only at one site, Boundary Bay Park. Defoliation levels increased at all other nontidal sites over the monitoring period.

\subsection{Beetle survival in tidal areas}

Survival of larvae in tidal areas was related to plant height. The tide in the night of June 14 was so high as to completely submerge the short Lythrum plants, but left the upper parts of the tall plants uncovered. Significantly more larvae disappeared from the short than from the tall stems $(Z=2.49, P=0.013)$ during the high tide. Starting with five larvae, $4.5 \pm 0.34$ larvae were recovered from the tall plants, on average, compared with only $2.2 \pm 0.54$ from the short plants.

\subsection{Variation in predation and plant quality among sites}

Average levels of beetle feeding damage on Lythrum at the four experimental sites ranged from a low of $22 \%$ at Iona South to a high of $88 \%$ at Westham (Table 2). Beetle density was highly variable between sites. On a per-stem basis, adult beetle density was highest at Iona South marsh, the site with the lowest larval feeding damage, with 1.3 beetles observed per minute in May of 2001 (Fig. 3). This was likely due to dispersal of adult beetles from the nearby Iona North site where severe defoliation resulted in a food shortage. Relative egg mass and larval densities were highest at Westham with 5.9 egg masses and 4.8 larvae observed per stem and per minute, respectively, but considerably lower at the other sites, approximately reflecting the subsequent defoliation levels.

Levels of predation on eggs were highly variable, ranging from a low of $7 \%$ at Westham to a high of $60 \%$ at Iona South (Table 2). Plant damage varied significantly with the level of predation on eggs ( $r=-0.98, n=4, P=0.02)$. Predation on eggs on stems surrounded by water was significantly lower than for stems on land with $20 \%$ versus $67 \%$, respectively $(Z=2.57, P=$ $0.01)$.

Predation on larvae was highest at Iona South marsh, where, on average, $46 \%$ of all larvae disappeared (Table 2), and lowest at Jericho with a disappearance of 22\%. Predation was similar and intermediate at Iona North marsh and Westham. Levels of predation on the larvae among sites were not significantly related to levels of plant feeding damage $(r=0.71, n=4$, $P=0.29)$.

Predation on pupae was lowest at Iona North marsh where, on average, 11\% of all pupae disappeared. The predation rates of pupae were intermediate at Iona South marsh and Jericho, respectively. The pupal predation rate was highest at Westham, where, on average, only 55\% of the experimentally deployed pupae were retrieved. Levels of pupal recovery were not significantly related to levels of plant defoliation $(r=-0.5, n=4, P=0.5)$. 
Plant quality, measured as the weight and as the survival, respectively, of larvae on caged plants was not significantly associated with the mean levels of feeding damage to plants among sites (larval weight: $r=-0.56, n=4, P=0.44$; larval survival: $r=-0.07, n=4, P=0.93$ ).

\subsection{Effect of Galerucella feeding on Lythrum}

Larval densities (Table 3) were strongly correlated with Lythrum defoliation levels $\left(r_{s}=\right.$ $0.94, n=6, P=0.005)$. Larval feeding apparently had a negative impact on the performance of Lythrum plants (Table 3): the flower-bud densities of the inflorescences $\left(r_{s}=-0.93, n=6\right.$, $P=0.008$; Fig. 4), the length of the inflorescences $\left(r_{s}=-0.93, n=6, P=0.008\right)$, and dry biomass of Lythrum per $\mathrm{m}^{2}\left(r_{s}=-0.89, n=6, P=0.02\right)$ were all significantly negatively correlated with the observed feeding damage levels in the same year. Flower-bud densities (square-root transformed) did not vary among the three tidal sites without Galerucella (MacDonald: $50.8 \pm$ 3.7; Deas: $49.5 \pm 1.8$; Ladner Marsh: $53.3 \pm 4.2$; Welch ANOVA, $F_{2,23.3}=0.21, P=0.81$ ), and thus, variation in flower-bud density at sites with beetles is likely due to beetle feeding damage. Stem height was marginally related to the observed feeding damage $\left(r_{s}=-0.77, n=6, P=0.07\right)$. Both the number of inflorescences per stem $\left(r_{s}=-0.1, n=6, P=0.87\right)$ and the stem densities $\left(r_{s}\right.$ $=-0.37, n=6, P=0.47$ ) of Lythrum were not related to the feeding damage among sites in 2000 .

Considering all nontidal sites, there was a significant and positive association between the average feeding damage between 1999 and 2002, measured by the mean flower-bud density (flower-bud density is significantly negatively associated with feeding density, Fig. 4), and the relative changes in stem density $\left(r_{s}=0.94, n=6, P>0.005\right.$, Fig. 5). Stem densities only decreased when the feeding activity was so intense as to inhibit flowering for four years, otherwise they increased; stem densities increased less when the average feeding damage was more intense. The stem density only decreased significantly at one site, Chilliwack (MannWhitney test, $Z=-2.30, P=0.021$; Table 3), where Lythrum plants had experienced complete defoliation for at least four consecutive years. Plant biomass apparently increased initially when the feeding damage started to increase at the Chilliwack, Westham, Iona South, and Colony Farm sites, but declined drastically when the grazing reached outbreak levels (Fig. 2). There were no apparent trends at sites where the beetle did not establish (MacDonald, Ladner, and Deas), or where beetle attack was negligible (Boundary Bay). At the Jericho site, Lythrum plants experienced consistent and complete defoliation in an unflooded part, while plants in a flooded area were not consistently attacked. The overall average defoliation level masks a high variability at this site.

\section{Discussion}

\subsection{General discussion}

The biological control of Lythrum salicaria by the beetle Galerucella calmariensis is generally considered to be successful (Blossey et al., 2001; Katovich et al., 2001; Landis et al., 2003; Lindgren, 2003), but may only be partially so in coastal British Columbia. In tidal areas,

the beetle failed to establish. Since the tidal water movement displaced Galerucella larvae over the short term, repeated disturbance events could severely impact larval survival, especially in early June, when Lythrum plants are small and completely submerged during high tide. Neonate larvae may be especially vulnerable due to their presumably reduced ability to hold on to the plant surface. Given the high rate of disappearance of larvae, we suggest that tidal disturbances 
may explain the failure of beetles to establish at any of the tidal sites. It is likely that the frequent disturbances also affect other life-history stages, including the oviposition behavior of Galerucella, since no eggs were found on plants in tidal areas. The observation that Galerucella was present at the MacDonald site for several years after the release was likely due to repeated dispersals to this site from the nearby Iona sites. We suggest that the beetle's inability to reproduce and develop in tidal areas prevents Galerucella from successfully establishing in this environment.

Four years of monitoring revealed high spatial and temporal variability in beetle feeding damage among nontidal sites. The rapid increase in the number of outbreak sites shows that the beetles are not generally prevented from reaching high densities and that they can exhibit rapid population growth. However, the presence of generalist, crawling predators may delay or hinder beetle outbreaks. Among the factors studied, only egg predation was significantly associated with the levels of herbivore feeding damage in a given year. Thus, this study suggests that predation influences beetle densities among sites. A range of generalist predators, among them ladybird beetles (Coleoptera: Coccinellidae), earwigs (Dermaptera: Forficulidae) and wolf spiders (Arachnida: Lycosidae), are known to effectively attack immature stages of Galerucella calmariensis and Galerucella pusilla, and may significantly reduce the populations of Galerucella (Sebold and Landis, 2004; Wiebe and Obrycki, 2004). The level of egg predation appears to be influenced by an abiotic factor, the water levels surrounding Lythrum stems in early spring. The strongly reduced egg predation on plants in standing water indicates that water can act as a barrier that prevents crawling predators from climbing the stems and preying on the beetle eggs. Such refuges from predators may allow small-scale (individual plant) beetle outbreaks, and could be potential starting points for larger outbreaks. If this finding applies generally, we predict that beetle outbreaks should start more commonly in years when winter precipitation is plentiful and in patches of plants in standing water, where high water levels in the spring protect the eggs from crawling predators. A significant decrease of the water level by the end of June observed at most sites would allow the beetles to pupate successfully in the soil. Adult overwintering success may not be affected by high water levels given the beetle's ability to use hollow plant stems as refuges in case of flooding (Schooler, 1998). While larval predation has been suggested as a force that could impact beetle populations (Sebolt and Landis, 2002), we did not find evidence for a consistent role of larval or pupal predation, or plant quality, in influencing beetle populations. However, the statistical power of these tests was low.

The results of this study suggest that the beetle is effective at reducing seed output and biomass of Lythrum. Our findings are in agreement with the results of other studies that have documented negative effects of herbivore feeding on the reproductive and vegetative performance of Lythrum (Blossey and Schat, 1997; Katovich et al., 1999, 2001; Lindgren, 2003). At least in the short term the reduction in seeds is not likely to translate into changes in the plant's population dynamics, given the plants' longevity and large seed bank in the soil (Welling and Becker, 1990). Nevertheless, the potential of Lythrum to spread is reduced because it occurs mainly by means of seeds (Mal et al., 1992). In addition, the reduced biomass of Lythrum under beetle attack will likely reduce its competitiveness (Gaudet and Keddy, 1988). The observation that plant stem height seemed only marginally related to the beetle feeding damage may be due to a lack of power in our analysis because the average stem height of Lythrum varied due to site conditions before the release of the beetle, but was not measured and thus, could not be included in the analysis. Katovich et al. (1999) and Lindgren (2003) found in their studies that beetle feeding reduced the height of Lythrum stems significantly. 
Previous research has shown that Lythrum is able to tolerate intense feeding of Galerucella spp. for more than two years before mortality occurs (Blossey and Skinner, 2000; Katovich et al., 1999). Consistent with this result, we found that Lythrum stem density decreased significantly at the Chilliwack site, which experienced the most consistent and intense feeding of all sites over the 4-year monitoring period. However, since quadrats with fewer than five stems were not considered for the monitoring, the estimates of decreases of plant density are conservative, and this may have prevented finding a significant reduction in stem densities at other sites.

To our knowledge, this is the first study to suggest that cumulative feeding may affect density and abundance of Lythrum. While four years of complete plant defoliation resulted in a reduction of stems, herbivory that was less intense was associated with an increase in stem density over the same time period. A possible explanation is that herbivory that does not result in complete defoliation causes seedling mortality only, thus limiting the growth of the population, while repeated, complete defoliation results also in the death of well-established plants and reduces the plant's population size. Alternatively, beetle feeding that does not result in complete defoliation may cause initial increases in the stem density of Lythrum, potentially by stimulating a morphological response in Lythrum, such as increased branching close to the soil surface. Clearly, experimental manipulations are needed to investigate the general applicability of the observed pattern and to determine the mechanism by which it is produced, since we cannot rule out the possibility that stem densities would also have increased in the absence of beetle feeding.

A reduction in plant biomass may be more important than a reduction in stem density alone in the context of competitive interactions. The reduction of dry biomass at the Chilliwack, Jericho, Westham, and Colony Farm site could benefit native species by reducing resource competition before Lythrum stem density is significantly reduced. The changes in plant biomass at the three tidal sites are likely due to yearly variation in abiotic conditions, since the beetle did not establish at these sites. This suggests that the consistent reductions of plant biomass at sites with considerable defoliation levels are caused by beetle attack. The observation that Lythrum biomass increased initially with increasing beetle grazing at many sites could indicate that Galerucella populations respond rapidly numerically to an increased plant abundance, and can successfully control the host plant at many nontidal sites.

\subsection{Implications for biological control}

Galerucella calmariensis appears to be only partly effective as a control agent of Lythrum salicaria in southwest British Columbia. The beetle does not appear to be a suitable control agent in tidal areas where tidal disturbances prevent its establishment. While the beetle established at all nontidal release sites and reduced the weed's seed output, it did not reduce Lythrum biomass and density at all sites by 2002. However, given the observed increase in sites with beetle outbreaks, we expect a decline in Lythrum abundance at more nontidal sites over time.

Our results highlight the importance of the abiotic environment at the introduction sites for the weed's and the beetle's population dynamics. While interference with native, generalist predators appeared to influence the abundance of Galerucella at a local scale, the abiotic environment may ultimately determine the balance of the trophic interactions and thus, the success of this biological control project at a regional scale. Biological control was apparently facilitated by the creation of temporary refuges from predation for the control agent in nontidal areas when water levels were high in the spring. In contrast, tidal areas act as a refuge for the 
weed, since disturbances associated with the water movement appear to prevent control agent establishment.

The failure of biological control in tidal areas raises concerns about the potential of these areas to serve as a consistent seed source from which new areas can be infested. The question of how Lythrum is regulated in tidal areas in its native range provides a valuable opportunity for ecological study and could also guide future management decisions such as the introduction of a suitable control agent into tidal areas for effective management of Lythrum on a regional scale.

\section{Acknowledgements}

We thank Janis Newhouse and Jennifer Passmore for their assistance in the field, the Langley Field Naturalists Society for their support for this project, and Jim Corrigan and Rosemarie DeClerck-Floate for providing Galerucella beetles. We are grateful to Fritz Denoth for his strong support throughout this project and for his help with the map. Financial support was provided by BC Hydro, the City of Langley, the Entomological Society of Canada, Environment Canada, the Habitat Conservation Trust Fund, the Integrated Vegetation Management Association of British Columbia, Mountain Equipment Co-op, NSERC, the Shell Environmental Fund, and VanCity Langley.

\section{References}

Anderson, M. G. 1991. Population Structure of Lythrum salicaria in Relation to Wetland Community Structure. M.Sc. Thesis. University of New Hampshire, Durham, USA.

Blossey, B. 1991. Biologie, Ökologie, Wirtsspezifität und Einfluss von Galerucella calmariensis L., G. pusilla Duft. (Col.:Chrysomelidae) und Hylobius transversovittatus Goeze (Col.:Curculionidae) auf ihre gemeinsame Wirtspflanze Lythrum salicaria L. (Blutweiderich). Ph.D. Thesis. Christian-Albrechts-Universitaet, Kiel, Germany.

Blossey, B. 1995. Coexistence of two leaf-beetles in the same fundamental niche. Distribution, adult phenology and oviposition. Oikos 74, 225-234.

Blossey, B., Schat, M. 1997. Performance of Galerucella calmariensis (Coleoptera: Chrysomelidae) on different North American populations of purple loosestrife. Environ. Entomol. 26, 439-445.

Blossey, B., Skinner, L. 2000. Design and importance of post-release monitoring. In: Spencer, N. R., (Ed.), Proceedings of the X International Symposium of Biological Control of Weeds. Montana State University, Bozeman, pp. 693-706. 
Blossey, B., Skinner, L. C., Taylor, J. 2001. Impact and management of purple loosestrife (Lythrum salicaria) in North America. Biodivers. Conserv. 10, 1787-1807.

Cameron, P. J., Hill, R. L., Bain, J., Thomas, W. P. 1993. Analysis of importations for biological control of insect pests and weeds in New Zealand. Biocontrol Sci. Technol. 3, 387-404.

Crawley, M. J. 1989. Insect herbivores and plant population dynamics. Annu. Rev. Entomol. 34, 531-564.

Cullen, J. M., Snowball, G. J. 1979. Factors limiting the success of biological control organisms. In: Anonymous (Ed.), Australian Applied Entomological Research Conference. Queensland Agricultural College, Lawes, pp. 141-161.

Denoth, M. 2004. Impact and Biological Control of Lythrum salicaria in Southwestern British Columbia. Ph.D. Thesis. University of British Columbia, Vancouver, Canada.

Gaudet, C. L., Keddy, P. A. 1988. A comparative approach to predicting competitive abilities from plant traits. Nature 334, 242-243.

Goeden, R. D., Louda, S. M. 1976. Biotic interference with insects imported for weed control. Annu. Rev. Entomol. 21, 325-342.

Hall, R. W., Ehler, L. E. 1979. Rate of establishment of natural enemies in classical biological control. Bull. Entomol. Soc. Am. 25, 280-282.

Hendrix, S. D. 1988. Herbivory and its impact on plant reproduction. In: Lovett-Doust, J., Lovett-Doust, L. (Eds.), Plant Reproductive Ecology: Patterns and Strategies. Oxford University Press, New York, pp. 246-263.

Hight, S. D., Drea, J. J. J. 1991. Prospects for a classical biological control project against purple loosestrife Lythrum salicaria L. Nat. Areas J. 11, 151-157.

Katovich, E. J. S., Becker, R. L., Ragsdale, D. W. 1999. Effect of Galerucella spp. on survival of purple loosestrife (Lythrum salicaria) roots and crowns. Weed Sci. 47, 360-365.

Katovich, E. J. S., Ragsdale, D. W., Skinner, L. C., Becker, R. L. 2001. Effect of Galerucella spp. feeding on seed production in purple loosestrife. Weed Sci. 49, 190-194. 
Keddy, P., Gaudet, C., Fraser, L. H. 2000. Effects of low and high nutrients on the competitive hierarchy of 26 shoreline plants. J. Ecol. 88, 413-423.

Landis, D. A., Sebolt, D. C., Haas, M. J., Klepinger, M. 2003. Establishment and impact of Galerucella calmariensis L. (Coleoptera: Chrysomelidae) on Lythrum salicaria L. and associated plant communities in Michigan. Biol. Control 28, 78-91.

Lindgren, C. J. 2003. Using 1-min scans and stem height data in a post-release monitoring strategy for Galerucella calmariensis (L.) (Coleoptera : Chrysomelidae) on purple loosestrife, Lythrum salicaria L. (Lythraceae), in Manitoba. Biol. Control 27, 201-209.

Loos, A., Jr., Ragsdale, D. 1998. Biological Control of Purple Loosestrife: A Guide for Rearing Leaf-feeding Beetles. Extension Bulletin FO-07080-GO. University of Minnesota, St. Paul, Minnesota.

Mal, T. K., Lovett-Doust, J., Lovett-Doust, L., Mulligan, G. A. 1992. The biology of Canadian weeds. 100. Lythrum salicaria. Can. J. Plant Sci. 72, 1305-1330.

Malecki, R. A., Blossey, B., Hight, S. D., Schroeder, D., Kok, L. T., Coulson, J. R. 1993. Biological control of purple loosestrife. BioScience 43, 680-686.

Manguin, S., White, R., Blossey, B., Hight, S. D. 1993. Genetics, taxonomy, and ecology of certain species of Galerucella (Coleoptera, Chrysomelidae). Ann. Entomol. Soc. Am. 86, 397410.

McAvoy, T. J., Kok, L. T., Mays, W. T. 1997. Phenology of an established population of Galerucella calmariensis (L.) and G. pusilla (Duft.) (Coleoptera: Chrysomelidae) on purple loosestrife, Lythrum salicaria L. (Lythraceae), in southwest Virginia. Biol. Control 9, 106-111.

McEvoy, P., Cox, C., Coombs, E. 1991. Successful biological control of ragwort, Senecio jacobaea, by introduced insects in Oregon. Ecol. Appl. 1, 430-442.

Medina, C. P. 1995. Coexistence Strategies and Hybridization of Galerucella calmariensis and G. pusilla (Coleoptera: Chrysomelidae), Biological Control Agents of Purple Loosestrife, Lythrum salicaria. Ph.D. Thesis. University of Guelph, Guelph, Canada.

Nechols, J. R., Obrycki, J. J., Tauber, C. A., Tauber, M. J. 1996. Potential impact of native natural enemies on Galerucella spp. (Coleoptera: Chrysomelidae) imported for biological control of purple loosestrife: A field evaluation. Biol. Control 7, 60-66. 
Rachich, J., Reader, R. J. 1999. An experimental study of wetland invasibility by purple loosestrife (Lythrum salicaria). Can. J. Bot. 77, 1499-1503.

Room, P. M. 1990. Ecology of a simple plant herbivore system - Biological control of Salvinia. Trends Ecol. Evol. 5, 74-79.

Schooler, S. S. 1998. Biological Control of Purple Loosestrife Lythrum salicaria by Two Chrysomelid Beetles Galerucella pusilla and Galerucella calmariensis. M.Sc. Thesis. Oregon State University, Corvallis, USA.

Sebolt, D. C., Landis, D. A. 2002. Neonate Galerucella calmariensis (Coleoptera: Chrysomelidae) behavior on purple loosestrife (Lythrum salicaria) contributes to reduced predation. Environ. Entomol. 31, 880-886.

Sebolt, D. C., Landis, D. A. 2004. Arthropod predators of Galerucella calmariensis L. (Coleoptera: Chrysomelidae): an assessment of biotic interference. Environ. Entomol. 33, 356361.

Shamsi, S. R. A., Whitehead, F. H. 1974. Comparative eco-physiology of Epilobium hirsutum L. and Lythrum salicaria L. 1. General biology, distribution and germination. J. Ecol. 62, 279-290. Sheppard, A. W. 1992. Predicting biological weed control. Trends Ecol. Evol. 7, 290-291.

Thompson, D. Q., Stuckey, R. L., Thompson, E. B. 1987. Spread, impact, and control of purple loosestrife (Lythrum salicaria L.) in North American wetlands. US Fish and Wildlife Service, Fish and Wildlife Research Report 2, Washington, DC.

Velarde, R. A. M., Wiedenmann, R. N., Voegtlin, D. J. 2002. Influence of photoperiod on the overwintering induction of Galerucella calmariensis L. BioControl 47, 587-601.

Welling, C. H., Becker, R. L. 1990. Seed bank dynamics of Lythrum salicaria L. - implications for control of this species in North America. Aquat. Bot. 38, 303-309.

Wiebe A.P. and Obrycki J.J. 2004. Quantitative assessment of predation of eggs and larvae of Galerucella pusilla in Iowa. Biol. Control 31, 16 - 28. 


\section{Denoth and Myers, Figure captions}

Fig. 1 Map showing experimental sites. (1 Jericho Beach park; 2 Iona North marsh; 3 Iona South marsh; $\boldsymbol{\Theta}$ MacDonald slough; $\boldsymbol{9}$ Westham Island; $\boldsymbol{0}$ Ladner marsh; $\boldsymbol{\theta}$ Deas Island; $\boldsymbol{8}$ Boundary Bay park; $\boldsymbol{\Theta}$ Colony Farm; $\boldsymbol{0}$ Chilliwack roadside (Yale road exit); 1 , and 99 are Highways.

Fig. 2 Average percentage Foliage removed (line graph, left y axis) and plant dry biomass per $\mathrm{m}^{2}$ (bar graph, right axis) in populations of Lythrum from 1999 to 2002. Plant dry biomass was not recorded at MacDonald in 2000. Dry biomass was estimated by the average dry biomass per stem per year and per site multiplied by the average number of stems at each site in August. Note different scales of plant biomass.

Fig. 3 Number (+ SEM) of adults, egg masses, and larvae of Galerucella observed per Lythrum stem and per minute at four experimental sites in 2001. Adult and egg-mass densities were recorded in mid-May, larval density in mid-June.

Fig. 4 Relationship between beetle feeding damage (arcsine transformed) and the mean flower-bud density per $5 \mathrm{~cm}$ of inflorescence of Lythrum (square-root transformed) $\left(r_{s}=-0.93, \mathrm{n}\right.$ $=6, P=0.008$ ).

Fig. 5 Relationship between the average beetle feeding damage, measured by the mean flower-bud density per $5 \mathrm{~cm}$ of inflorescence of Lythrum from 1999 to 2002, and changes in stem densities (in percent of stem density in 1999) between 1999 and 2002 at nontidal sites $\left(r_{s}=\right.$ $0.94, \mathrm{n}=6, P<0.005)$. 


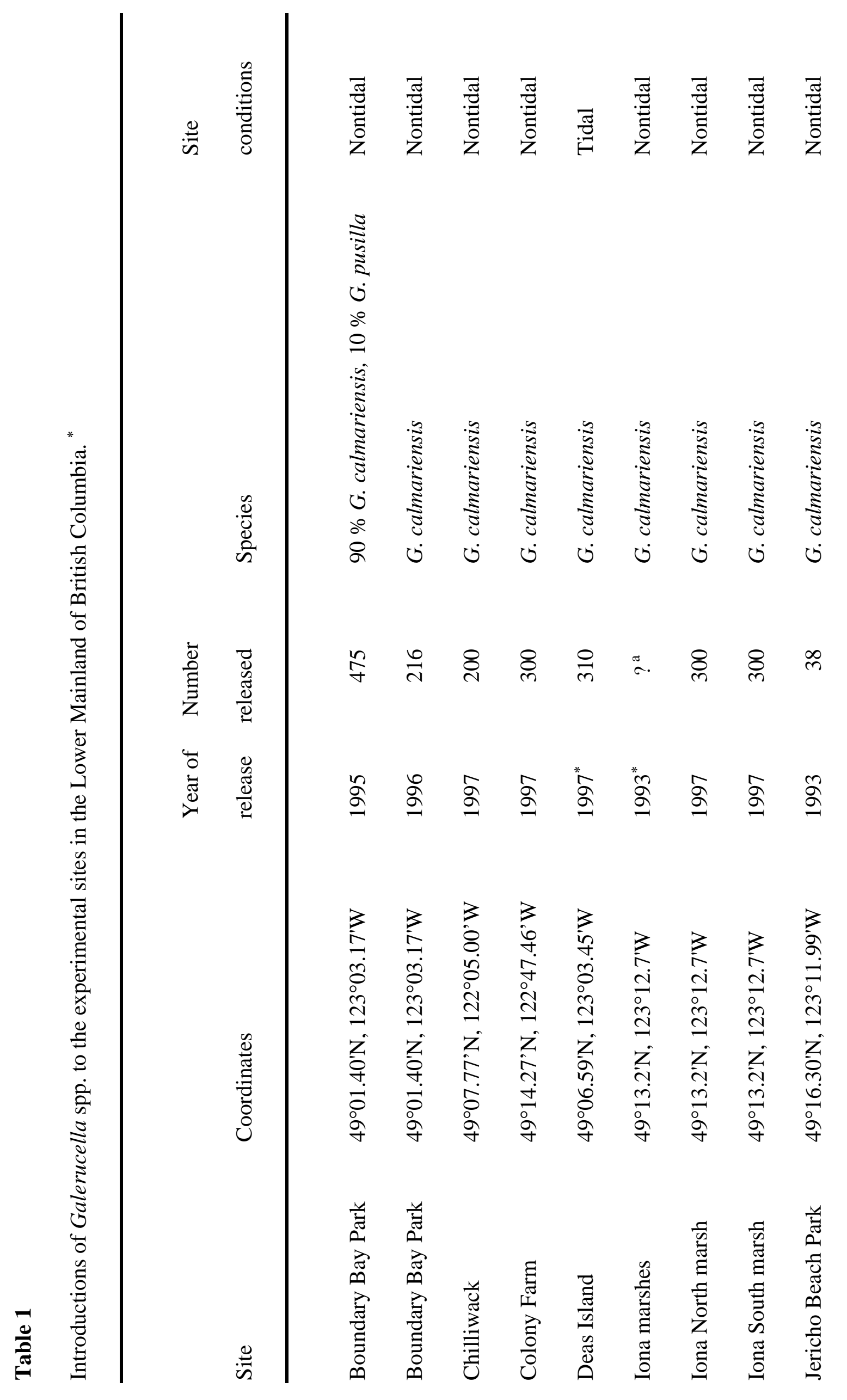




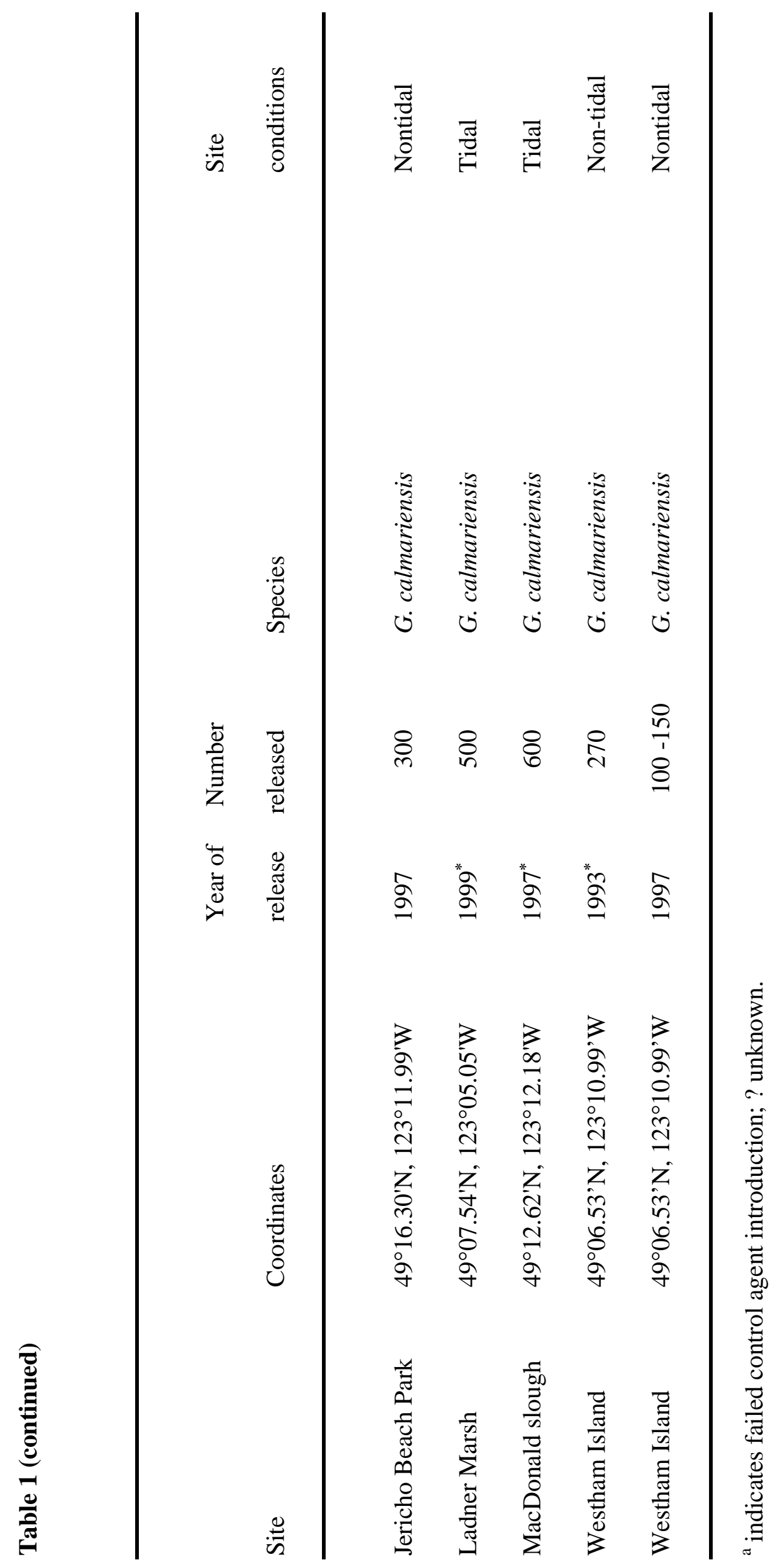




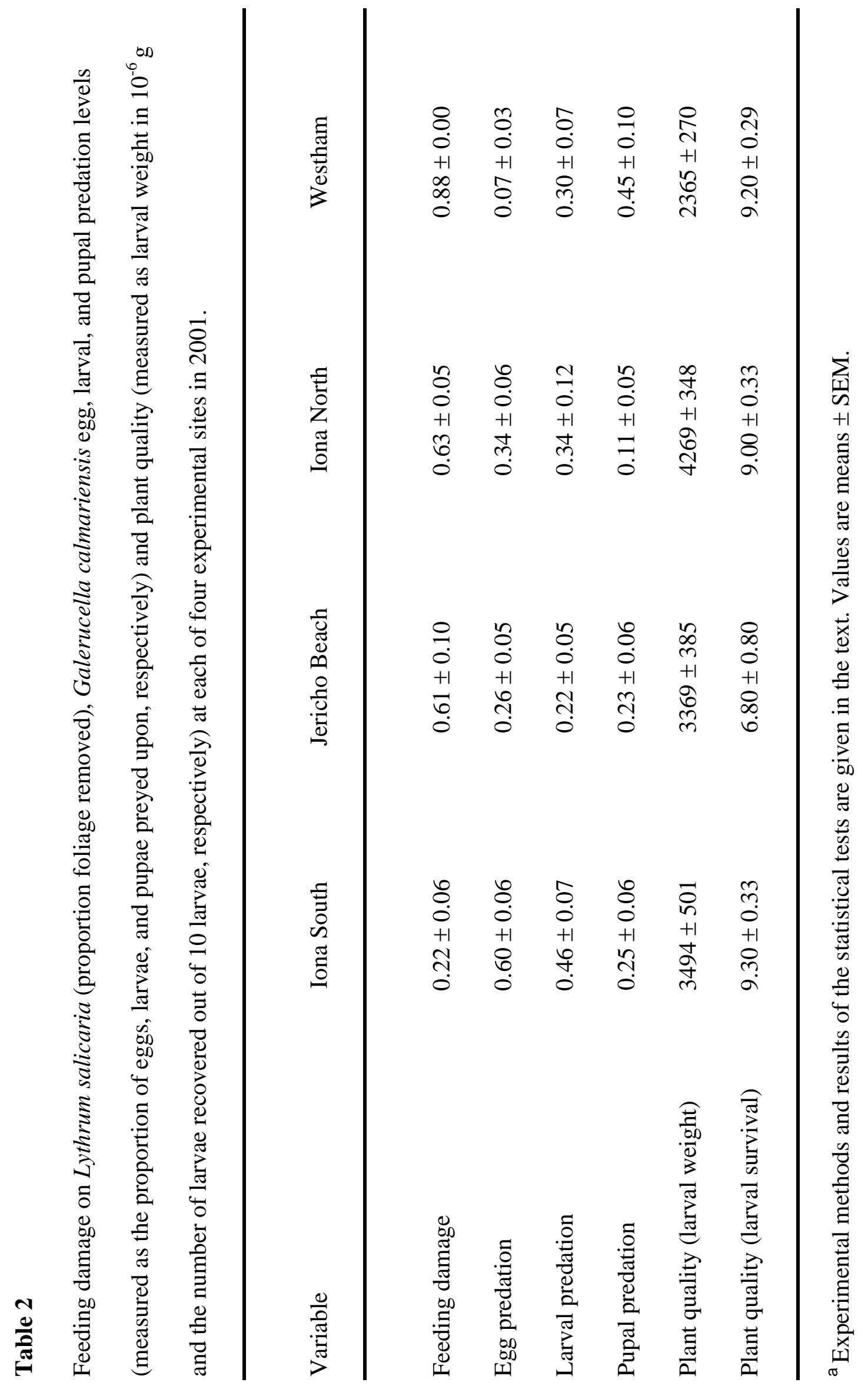




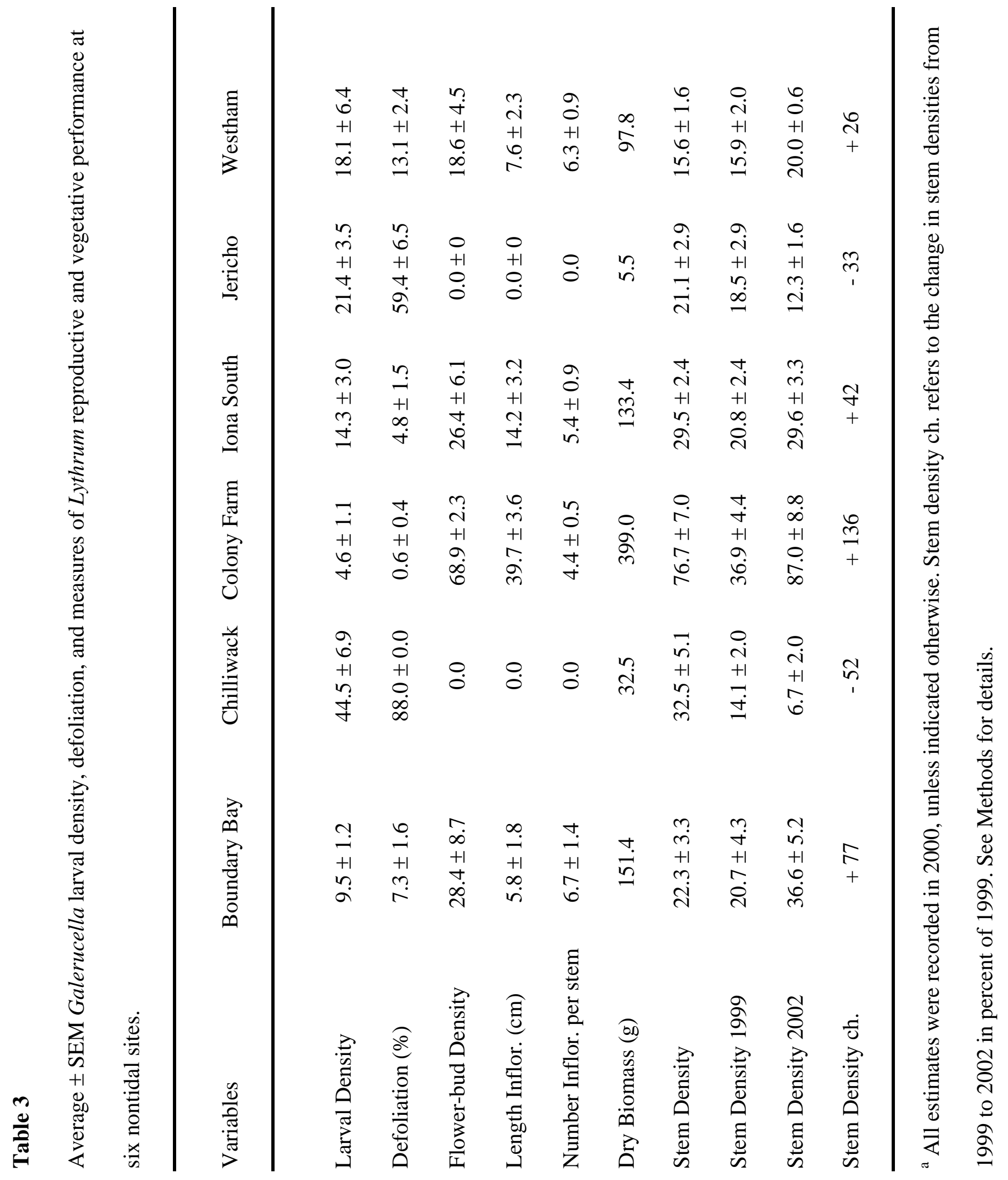




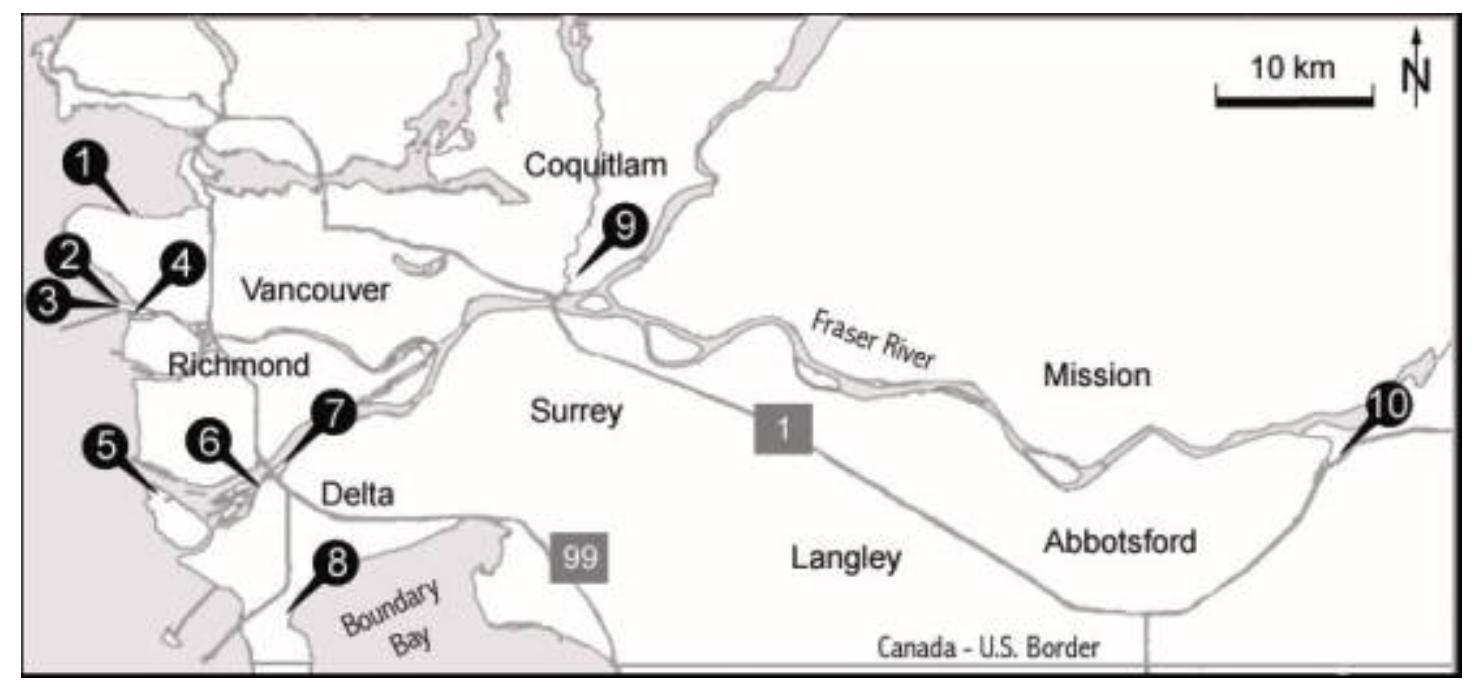

Fig. 1 

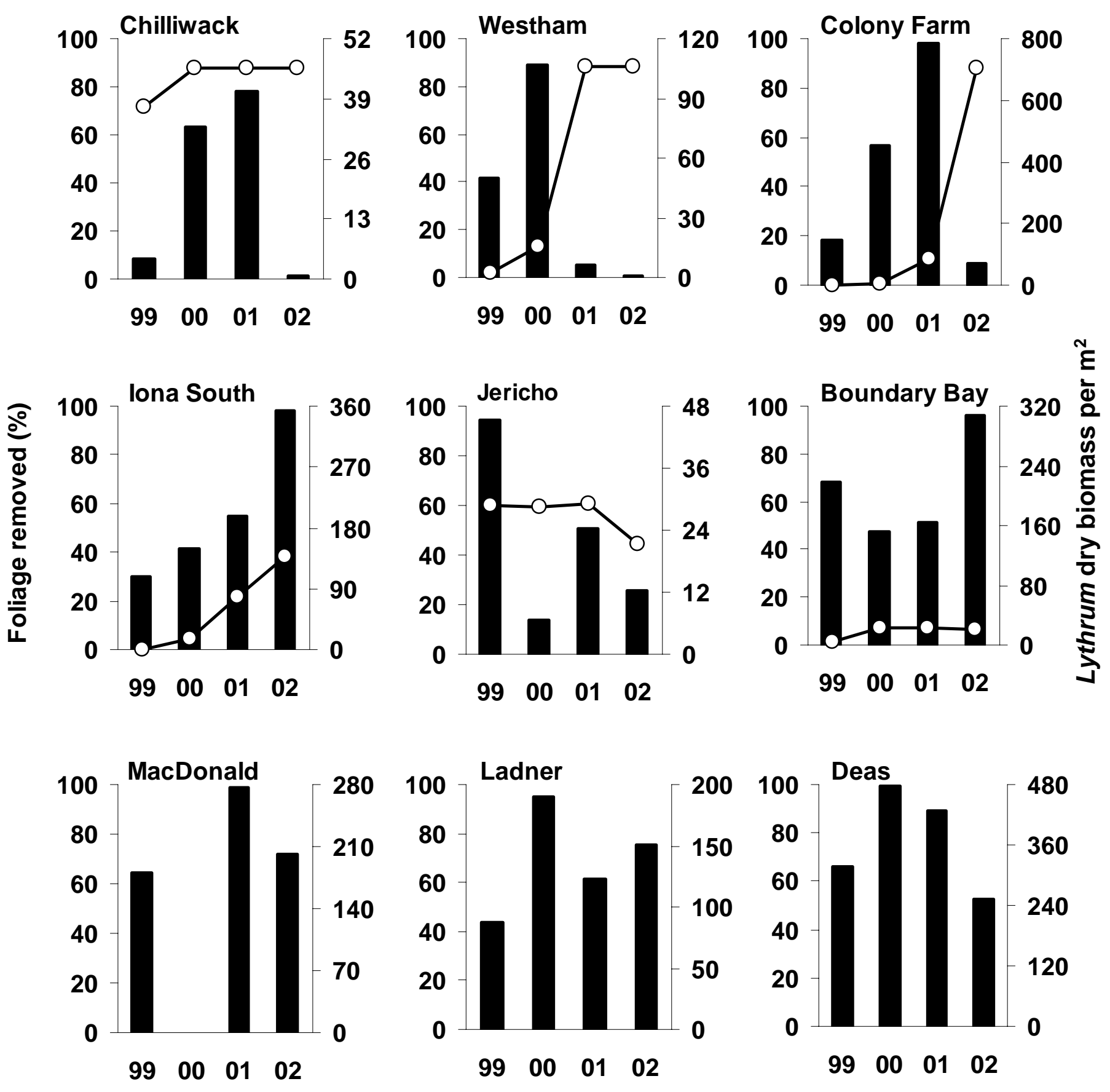

Fig. 2 


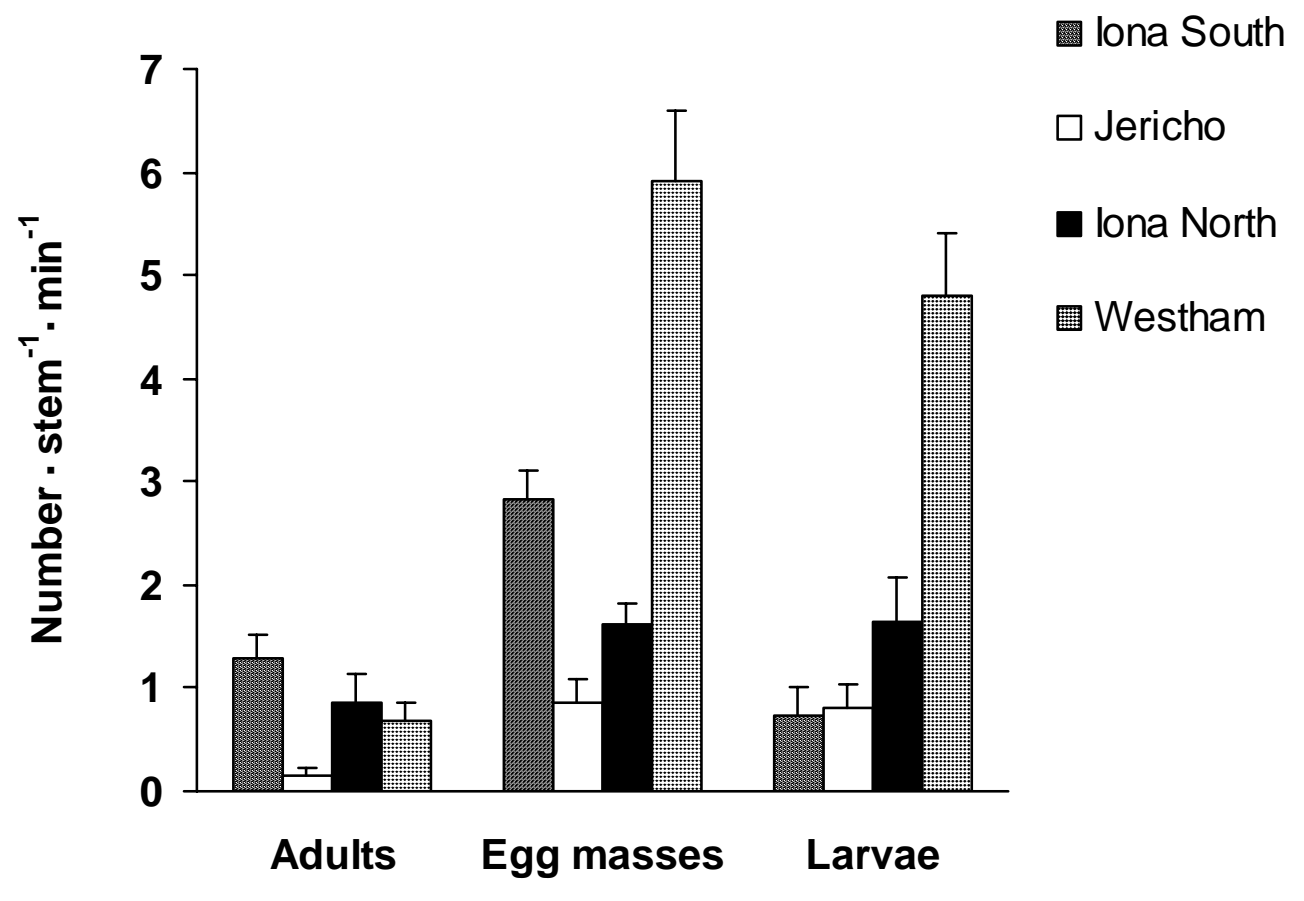

Fig. 3 


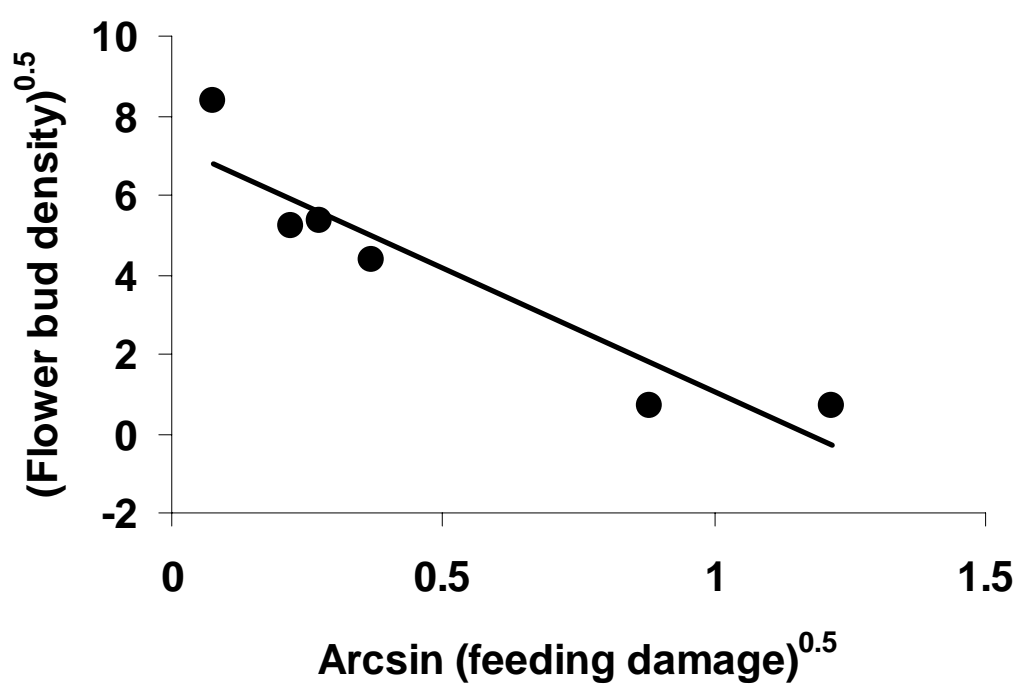

Fig. 4 


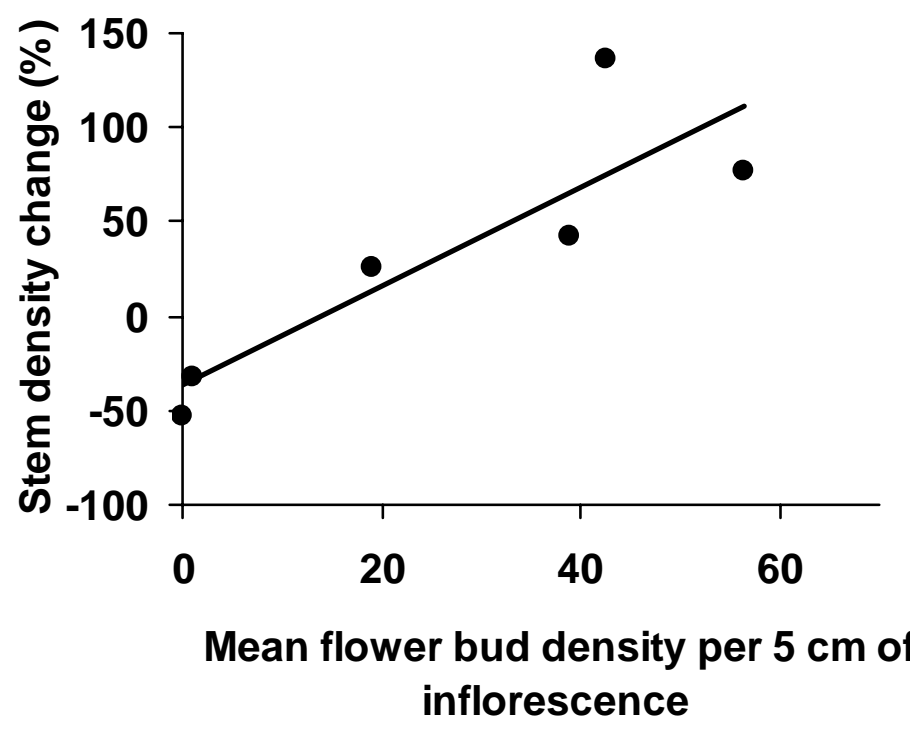

Fig. 5 